\title{
PERBANDINGAN ELIMINASI LAKTAT MENGGUNAKAN METODE RECOVERY AKTIF (JOGGING) DAN RECOVERY AKTIF (JOGGING) PLUS MASASE
}

\author{
Asep Nugraha, Sumardiyanto, Iman Imanudin \\ Program Studi Ilmu Keolahragaan \\ Departemen Pendidikan Kesehatan dan Rekreasi \\ Fakultas Pendidikan Olahraga dan Kesehatan \\ Universitas Pendidikan Indonesia, Jl. Dr. Setiabudhi No. 229 Bandung \\ Email : aspnugraha27@gmail.com
}

\begin{abstract}
Abstrak
Tujuan penelitian ini adalah untuk membandingkan eliminasi laktat menggunakan metode recovery aktif (jogging) dan recovery aktif (jogging) plus masase . 21 mahasiswa ilmu keolahragaan angkatan 2015 berpartisipasi menjadi sampel penelitian ini. Desain penelitian yang digunakan adalah Randomized Pretest Posttest Control Group Design. Sampel dibagi kedalam tiga kelompok berdasarkan perlakuan yang diberikan, yaitu kelompok recoveri aktif (jogging), recovery aktif (jogging) plus masase, dan kontrol. Setiap kelompok melakukan tes Cunningham and Faulkner untuk merangsang terjadinya akumulasi laktat. Setelah itu, setiap kelompok diberikan perlakuan recovery aktif (jogging), recovery aktif (jogging) plus masase dan kontrol (tidak diberikan perlakuan). Durasi recovery selama 15 menit setiap kelompoknya dengan intensitas sedang 55-69\% denyut nadi maksimal. Hasilnya, setiap kelompok mengalami eliminasi laktat yang signifikan setelah diberikan perlakuan dengan presentase laktat yang tereliminasi $46.02 \%$ (jogging), 26.42\% (jogging plus masasei), $22.93 \%$ (kontrol). Selain itu, terdapat perbedaan signifikan eliminasi laktat $(0.035<0.05)$. hasil uji lanjut, perbedaan eliminasi laktat terjadi antara kelompok jogging dengan kelompok kontrol yang signifikan $(0.049<0.05)$ sedangkan kelompok joging dengan joging plus masase joging plus masase dengan control tidak signifikan $(0.071>$ 0.05. Dengan demikian, dapat dinyatakan bahwa metode recovery aktif jogging dan recoveri aktif jogging plus masase memiliki pengaruh yang sama terhadap eliminasi asam laktat.

Kata kunci: Recovery aktif, jogging, Masase, Eliminasi Laktat, Durasi, Intensitas.
\end{abstract}

\section{PENDAHULUAN}

Kelelahan merupakan hasil dari penurunan produksi ATP yang dihubungkan dengan adanya perubahan enzim, perubahan mekanisme membran transport, dan perubahan ketersediaan subtrat. "Metabolic fatigue results from a reduced production of ATP linked to enzyme changes, changes in membrane transportmechanisms, and changes in substrate availability" (Plowman \& Smith, 2011). Proses kelelahan seringkali terjadi pada saat latihan intensitas tinggi, "During training of high intensity, athletes experience fatigue..." (Tokmakidis dkk., 2011) dan pada kompetisi yang menjalani pertandingan berulang-ulang dengan jeda waktu yang singkat (satu hari atau kurang dari 24 jam), “...athletes often participate in repeated events within a competition" (Tokmakidis., 2011). Pada 
akhirnya, kelelahan akan menyebabkan penurunan performa. "The decrement in performance associated with lactic acid results from fatigue that is both metabolic and muscular in origin" (Plowman \& Smith, 2011).

Laktat adalah salah satu penyebab terjadinya kelelahan, "In the past, lactate was believed to be a factor contributing to fatigue..." (Tokmakidis., 2011). Hal tersebut berlandaskan pada dua hal. Pertama, laktat akan mencegah actomiosin ATPase dan enzim untuk memecah ATP menjadi energi pada saat kontraksi otot. "The first is an inhibition of actomyosin ATPase, the enzyme responsible for the breakdown of ATP to provide the immediate energy for muscle contraction" (Plowman \& Smith, 2011). Kedua, adanya ion hydrogen akan terjadi penyerapan kalsium yang dimana dibutuhkan untuk kontraksi dan relaksasi otot. "The second is an interference of $\mathrm{H}+$ with the actions and uptake of calcium (Ca2+) that is necessary for the excitation-contraction coupling and relaxation of the protein crossbridges within the muscle fiber" (Plowman \& Smith, 2011).

Proses munculnya laktat adalah ketika asam piruvat terbentuk pada proses metabolisme glikolisis anaerob dan terkonversikan menjadi asam laktat oleh enzim laktatdehidrogenase "The reason for lactate accumulation is that more of the pyruvate is converted to lactate by lactate dehydrogenase..." Gladden (dalam Menzies et.al., 2015). Laktat akan terakumulasi pada olahraga atau latihan yang memiliki karakteristik intensitas tinggi. "Work of high intensity that it can be performed continuously only for a short period of time is accompanied by a high rate of glycogen depletion, lactate accumulation and a greater contribution of carbohydrate to oxidative metabolism" (Gur, 2015). Olahraga yang menuntut pengerahan tenaga dengan intensitas tinggi seperti Climbing (Valenzuela dkk., 2015), Basketball (Araujo dkk., 2013), dan Soccer (Falco, 2015).

Walaupun akumulasi laktat menjadi penyebab terjadinya kelelahan, akumulasi laktat juga dapat dikonversikan menjadi bahan bakar energi melalui proses difusi laktat dari otot menuju aliran darah. "The lactate formed in fast twitch muscle fibers can diffuse out of the muscle and enter the blood or it can shuttle directly to adjacent slow twitch muscle fibers where the lactate can be consumed as a fuel" (Gur, 2015). Blood flow memfasilitasi pengkonversian laktat menjadi energi, "oxidation of the excess lactate relies on redistribution by the blood flow to other muscles and the heart and liver" Gladden (dalam Menzies dkk., 2015).

Recovery aktif adalah metode yang paling efektif untuk meeliminasi laktat dikarenakan akan mengaktifkam muscle blood flow yang akan memfasilitasi pengkonversian laktat menjadi energi. “...Active Recovery may increase the efflux and flow of lactate to other tissues for oxidation" Lindinger (dalam Tokmakidis, 2011). Oleh karena itu Beberapa penelitian telah menemukan bahwa Recovery aktif lebih baik dibandingkan Recovery pasif. "Numerous studies have found improved lactate removal and/or performance with active rather than with passive Recovery in different types of exercise" Wells (dalam Valenzuela dkk, 2015). Penelitian yang dilakukan Monedero \& Donne (2000) menyatakan bahwa tidak terdapat perbedaan antara recovery pasif dengan masase akan tetapi kombinasi masase dengan Recovery aktif lebih baik dibandingkan dengan masase.

Selain itu, penelitian sebelumnya sudah membuktikan bahwa perbandingan jenis Recovery aktif berenang lebih baik dibandingkan bersepedah dan lari dalam meeliminasi laktat. "Lactate removal rate after active Recovery was higher during swimming, 
compared to cycling or running" (Tokmakidis, 2011).

Cabang olahraga futsal dan sepakbola sering kali menjalani kompetisi atau turnamen dengan interval waktu yang saling berdekatan dari satu pertandingan ke pertandingan lainya. Hal tersebut akan menyebabkan kelelahan pada atlet yang pada akhirnya performa atlet akan menurun dikarenakan adanya laktat yang terakumulasi. Proses Recovery menjadi satu hal penting dalam meeliminasi laktat dan menjaga performa atlet. Oleh karena itu, dalam penelitian ini peneliti mencoba membandingan Recovery aktif jogging dan kombinasi recoveri aktif jogging dengan masase untuk mencari bentuk Recovery yang lebih efektif dalam meeliminasi laktat. Pada akhirnya, penelitian ini dapat diaplikasikan oleh pelatih cabang olahraga sepakbola dan futsal sebagai metode Recovery yang tepat untuk memulihkan atlet dari kelelahan setelah latihan atau pertandingan.

\section{METODE}

Partisipan dalam penelitian ini berjumlah 21 orang mahasiswa ilmu keolahragaan yang aktif bermain futsal dan sepakbola. Subjek akan dibagi kedalam tiga kelompok yaitu kelompok recovery jogging, recovery jogging plus masase, dan kontrol. Sebelumnya, subjek diberikan informasi mengenai teknis dan prosedur penelitian ini.

Metode penelitian kuantitatif yang diterapkan dalam penelitian ini adalah eksperimen. "Metode eksperimen dapat diartikan sebagai metode penelitian yang digunakan untuk mencari pengaruh perlakuan tertentu terhadap yang lain dalam kondisi yang terkendalikan" (Sugiyono, 2016). Jenis metode eksperimen yang digunakan adalah pretest posttest kontrol group design, yang dimana peneliti mencoba untuk menguji perbedaan eliminasi laktat pada tes awal dan tes akhir setelah diberikan treatmen Recovery (jogging dan kombinasi jogging plus masase) dan kontrol grup

Pada penelitian ini, instrument yang digunakan adalah Accutrend Lactate (Lactate Finger Prick) dan Polar Heart Rate Monitor. Accutrend Lactate berfungsi untuk mengukur konsentrasi laktat di dalam aliran darah dan polar heart rate monitor berfungsi untuk memonitor detak jantung selama melakukan tes.

Pengambilan data penelitian merupakan proses inti dari tahapan pelaksanaan penelitian. Penelitian tidak akan berakhir jika tidak ada data yang diolah. Proses pengambilan data penelitian ini dibagi ke dalam beberapa tahapan tes, yaitu:

\section{a. Tes BMI}

Tes BMI dimasukan ke dalam bagian prosedur penelitian dikarenakan perannya sangat penting untuk mengetahui apakah sampel mempunyai index masa tubuh yang normal atau overweight.

\section{b. Tes Cunningham and Faulkner}

Cunningham And Faulkner Tes merupakan intrumen tes untuk mengevaluasi kapasitas anerobik. Peneliti menggunakan tes tersebut untuk merangsang terjadinya akumulasi laktat.

\section{c. Tes laktat awal}

Tes laktat awal dilakukan langsung setelah sampel melaksanakan tes Cunningham And Faulkner. Tes laktat pertama berfungsi untuk mengetahui nilai laktat yang terakumulasi.

\section{d. Recovery Aktif}

Pemberian recovery aktif sebagai metode untuk meeliminasi akumulasi laktat. Metode yang digunakan dalam penelitian ini adalah jogging selama 15 menit (1 grup) dan kombinasi jogging plus masase (1 grup). 


\section{Lari}

Lari dilakukan di atas treadmill selama 15 menit dengan kecepatan $5 \mathrm{~km} / \mathrm{jam}$ dan incline $0 \%$. Metode lari diberikan sebagai rangsangan terjadinya muscle blood flow yang akan memfasilitasi eliminasi laktat.

\section{Masase Plus Lari}

Masase menjadi salah satu metode relaksasi yang digunakan sebelum dan setelah latihan fisik. Dalam penelitian ini mencoba untuk menggunakan masase sebagai metode yang dapat meeliminasi laktat di dalam darah. Teknik masase yang digunakan adalah kneading compression. Akan tetapi, metode masase akan digabung dengan lari dengan proporsi waktu 7 menit lari dan 8 menit masase total waktu keseluruhannya 15 menit.

\section{e. Tes Laktat Terakhir}

Tes laktat terakhir dilakukan langsung setelah sampel diberikan metode Recovery aktif lari atau lari plus masase. Tes laktat terakhir berfungsi untuk mendapatkan nilai laktat yang tereliminasi setelah diberikan metode Recovery akif .

Proses Analisis data penelitian ini menggunakan Statistical Produk and Service Solution (SPSS) versi 19.0 for windows. Teknik analisi data dibagi menjadi dua tahap. Pertama, setiap kelompok dilakukan uji beda rata-rata kempok berpasangan (pretest dengan posttest) menggunakan teknik analisis paired sample t-test. Setelah itu, dilakukan uji beda tiga kelompok (lari, masase plus lari, dan kontrol) menggunakan teknik analisis one way ANOVA.

\section{HASIL DAN PEMBAHASAN}

Nilai eliminasi laktat setiap kelompok memiliki nilai berbeda, nilai eliminasi laktat tertinggi terjadi pada kelompok jogging 12.55 menjadi 6.72 dengan jumlah selisih atau laktat yang tereliminasi 5.82 (46.02\%). sedangkan pada kelompok jogging plus masase (9.00 menjadi 6.21) dan kontrol (10.97 menjadi 8.43) cenderung mengalami penurunan yang sama, dengan nilai selisih $2.78(26.42 \%)$ dan 2.54 (22.93\%).Selain itu eliminasi laktat memiliki perbedaan signifikan dengan nila $\mathrm{p}<0.05$, kelompok recovery lari $0.001<0.05$, kelompok masase plus lari 0.045 $<0.05$, dan kelompok kontrol $0.003<0.05$. hal tersebut menandakan bahwa terdapat perbedaan nilai laktat pretest dan posttest yang berarti terdapat pengaruh recovery setiap kelompok terhadap nilai eliminasi laktat.

Perbandingan nilai rata-rata kelompok lari, masase plus lari, dan kontrol menyatakan bahwa nilai signifikansi/ probabilitas 0.035 atau $0.035<0.05$. hal tersebut menunjukan terdapat perbedaan rata-rata eliminasi laktat antara kelompok recovery jogging, recovery jogging plus masase, dan kontrol.

Hasil data uji post hoc tukey menyatakan interaksi kelompok lari dan masase plus lari memiliki sig. $=0.071$ atau $0.071>0.05$ dapat diartikan bahwa tidak terdapat perbedaan eliminasi laktat antara kelompok jogging dan jogging plus masase. Interaksi pada kelompok jogging dan kontrol memiliki nilai sig. 0.013 atau 0.013 $<0.05$ dapat diartikan terdapat perbedaan eliminasi laktat antara kelompok jogging dan kontrol. Interaksi pada kelompok jogging plus masase dan kontrol memiliki sig. $=0.980$ atau $0.980>0.05$ dapat diartikan bahwa tidak terdapat perbedaan eliminasi laktat pada kelompok jogging plus masase dan kontrol

Laktat adalah produk akhir dari proses metabolisme glikolisis anaerobic. "Lactic acid is produced in muscle cells when the NADH + $H+$ formed in glycolysis is oxidized to NAD+ by a transfer of the hydrogen ions to pyruvic acid (C3H4O3), which in turn is reduced to 
lactic acid (C3H6O3)" (Plowman dan Smith, 2011). Laktat menjadi hal yang sangat penting dikarenakan laktat menjadi indikasi terjadinya kelelahan otot dan penurunan performa, “...it has been recognized that elevated concentrations of skeletal muscle and blood lactate are associated with impaired muscle function and exercise performance" (Menzies, 2010). Selain itu, Brooks (dalam Menzies, 2010) menyatakan bahwa:

"that accumulation of lactate may at least indirectly contribute to reduced performance, because conversion of lactic acid to lactate releases $H p$ that leads to a metabolic acidosis with subsequent inhibition of glycolytic rate-limiting enzymes, lipolysis, and contractility of the skeletal muscles".

Laktat akan tereliminasi dengan mengkonversikan laktat menjadi bahan bakar energi yang melalui tiga proses yaitu oksidasi, glukogeogenesis, dan transminasi. "Lactate clearance occurs primarily by three processes: oxidation gluconeogenesis/glyconeogenesis (10-25\%), and transamination (5-10\%)" (Plowman \& Smith, 2011). Laktat akan tereliminasi lebih efektif dengan Recovery aktif dibandingkan Recovery pasif. Hal ini seperti yang dinyatakan oleh Mondero \& Donne (dalam Menzies, 2010) “...that active Recovery clears blood lactate faster than passive Recovery...".Menurut penelitian Bonen dan elcastro (1976) menyatakan bahwa proses Recovery dengan lari intensitas $61.4 \%$ Vo2max dan durasi selama 15 sampai 25 menit akan menurunkan laktat darah yang signifikan dibandingkan dengan pasif Recovery.

Penentuan intensitas pada saat melakukan Recovery adalah dengan indikator denyut nadi maximal dengan rumus 220 - Usia, presentase intensitas 55 - $69 \%$ (moderat). Akan tetapi, indicator intensitas seharusnya dengan lactate threshold agar lebih efektif dalam mengeleminasi laktat, dengan presentase intensitas 10\% dibawah laktat threshold, seperti yang diungkapkan McLellan \& Skinner (dalam Powell, 2011) "...that the most effective intensity of active Recovery for lactate removal is related to the individual "anaerobic threshold", suggesting that an intensity of $10 \%$ of VO2 max below the "anaerobic threshold" is the most efficient". Durasi aktif Recovery selama 15 menit cukup untuk meeliminasi laktat dibandingkan dengan pasif Recovery, seperti yang diungkapkan Tokmakidis dkk. (2011) "...that 10 to 15 minutes of active Recovery is adequate to reduce blood lactate compared to passive Recovery". Teori tersebut terbukti dengan adanya perbedaan eliminasi laktat antara kelompok lari dan kontrol dengan nilai sig. 0.013 atau $0.013>0.05$. Pada intinya, penentuan intensitas dan durasi pada saat Recovery berfungsi untuk merangsang muscle blood flow (MBF) karena dengan adanya MBF akan membantu dalam suplai energi dan homeostatis tubuh. Sjogaard (dalam Powell, 2011). "Adequate muscle blood flow is important for energy supply and maintenance of homeostasis in the muscle and plays a critical role in the prevention of muscular fatigue”.

Hasil pengolahan data menyatakan bahwa terdapat perbedaan eliminasi laktat di setiap kelompoknya dengan nilai sig. $=0.035$ atau $0.035<0.05$ yang menyatakan bahwa Ho ditolak. Berarti Terdapat perbedaan rata-rata laktat setelah dan sebelum recovery jogging, kombinasi jogging plus masase, dan pasif Recovery (kontrol).

Akan tetapi, setelah di uji Post Hoc Tukey menyatakan bahwa interaksi antara recovery jogging dan kombinasi jogging plus masase tidak memiliki perbedaan, dengan nilai sig. $=0.071$ atau $0.071>0.05$. artinya, kedua metode tersebut dapat dikatakan sama untuk mengeliminasi laktat. Kurangnya intensitas dan durasi recovery yang menyebabkan tidak adanya perbedaan diantara kedua metode tersebut. 
Walaupun tidak adanya perbedaan eliminasi laktat antara metode jogging dan kombinasi jogging plus masase, namun pada setiap kelompok mengalami penurunan laktat secara signifikan menandakan bahwa di dalam setiap kelompok terjadi perbedaan rata-rata eliminasi laktat. Oleh karena itu para pelatih dapat mengaplikasikan hasil penelitian ini dengan menerapkan metode aktif recovery jogging atau jogging plus masase selama 15 menit, dengan intensitas sedang (55-69\% dari denyut nadi maksimal).

\section{KESIMPULAN}

Hasil penelitian ini menyimpulkan bahwa setiap kelompok setelah diberikannya recovery aktif dan kombinasi masase megalami eliminasi laktat yang signifikan. Selain itu, terdapat eliminasi laktat yang signifikan pada setiap kelompok, nilai perbandingan eliminasi laktat antara metode recovery aktif jogging dan kombinasi plus masase dan kontrol menyatakan adanya perbedaan yang signifikan. Secara dekriptif dapat dinyatakan bahwa recovery jogging memiliki nilai eliminasi laktat yang lebih tinggi dibandingkan kelompok lainnya. Oleh karena itu, recovery jogging lebih efektif dalam eliminasi laktat dibandingkan kombinasi jogging plus masase dan kontrol.

Mengacu pada hasil penelitian ini, para pelatih ataupun para praktisi olahraga prestasi dianjurkan menerapkan metode jogging dibandingkan kombinasi jogging plus masase, setelah melakukan latihan atau kompetisi agar dapat menurunkan nilai akumulasi laktat.

Para peneliti dapat menjadikan hasil penelitian ini sebagai dasar untuk melanjutkan penelitian lebih luas mengenai metode recovery aktif menggunakan metode yang sama dengan memanipulasi durasi recovery lebih dari 15 menit. Selain itu, penelitian selanjutnnya dapat dimodifikasi dengan jumlah sampel yang lebih besar.

Beberapa saran dari peneliti untuk penelitian berikutnya adalah perlu adanya penggantian tabung kompresor dengan yang lebih kuat dan besar, agar tekanan udara yang dihasilkan bisa lebih besar sehingga kecepatan akan lebih bertambah dan tambahkan penggunakan listrik apabila batre sudah habis. Jadi apabila batre habis, bisa menggunakan listrik sebagai alternatif lain.

\section{DAFTAR PUSTAKA}

Araujo, G. D., Papoti, M., Camargo, B. H., \& Gobatto, C. A. (2013). Anaerobic and Aerobic Performances in Elite Basketball Players. Journal of Human Kinetics, 137-147.

Couturier, A. (2013). Massage and Physiotherapy. In C. Hausswirth, \& I. Mujika, Recovery for Performance in Sport (p. 111). Champaign: Human Kinetics.

Falco, A. D. (2015). PHYSIOLOGY OF SOCCER: A REVIEW. Journal of Australian Strength and Conditioning, 85-90.

Gur, E. (2012). A Comparison of Blood Lactate Level and Heart Rate Following a Peak Anaerobic Power Test in Dufferent Exercise Loads. European Journal of Experimental Biology, 1854-1861.

Hausswirth, C., \& Mujika, I. (2013). Recovery for Performance in Sport. Canada: Human Kinetics. 
Ishii, I., \& Nishida, Y. (2013). Effect of Lactate Accumulation during Exercise-Induced Muscle Fatigue on the Sensorimotor Cortex. Journal of Physical Therapy Science, 1637-1642.

Mackenzie, B. (2005). 101 Performance Evaluation Tests. London: Electric Word plc.

Menzies, P., Menzies, C., Mcintyre, L., Paterson, P., Wilson, J., \& ole, K. J. (2010). Blood lactate clearance during active recovery after an intense running bout depends on the intensity of the active recovery. Journal of Sport Science, 975-982.

Mondero , J., \& Donne, B. (2000). Effect of Recovery Interventions on Lactate Removal and Subsuequent Performance. International Journal of Sport Science, 593-597.

Plowman, S. A., \& Smith, D. L. (2011). Exercise Physiology For Heath, Fitness, And Performance. Philadhelphia: Lippincott William \& Wilkins.

Powell, Mark A. (2011). Physical Fitness : Training, Effect, And Maintaining. New york: Nova Science Publisher.

Sugiyono. (2016). Metode Penelitian Pendidikan Pendekatan Kuantitatif, Kualitatif, dan R\&D. Bandung: Alfabeta.

Tokmakidis, S. P., Toubekis, A. T., \& Smilios, I. (2011). Active versus Passive Recovery :Metabolic Limitations And Performance Outcome. In M. A. Powell, Physical Fitness Training, Effect and Maintaining (pp. 1-43). New York: Nova Science Publisher.

Valenzuela , P. L., Villa, d. P., \& Ferragut, C. (2015). Effect of Two Types of Active Recovery on Fatigue and Climbing Performance. Journal of Sport Science and Medicine, 769-775. 